\title{
Influence of Prolonged Salting on the Physicochemical Properties of Duck Egg White
}

\author{
Karthikeyan Venkatachalam ${ }^{1^{*}}$ \\ ${ }^{I}$ Department of Food Technology, Faculty of Science and Industrial Technology, Prince of Songkla University, \\ Makhamtia, Muang, Surat Thani - 84000, Thailand
}

\begin{abstract}
Salted duck eggs are unique among the important authentic foods of Thailand. They are mainly produced in Chaiya district, Surat Thani province, in the southern part of Thailand. The egg whites of salted duck eggs are normally unusable due to heavily salty taste upon prolonged storage. The present study was aimed to examine the foaming characteristics of egg white after being cured for a prolonged period (30 days). At 5-day intervals the egg whites were measured for salt, moisture, water activity, hydrophobicity, pH, zeta potential, particle size, SH groups, surface tension and foaming properties (index of whipping, foam durability, specific density, overrun, air phase and yield stress). The results showed that prolonged curing significantly affected egg white and its foam. Salt content, hydrophobicity, particle size, and exposed SH groups gradually increased with storage period. On the other hand, moisture, water activity, pH, zeta potential, surface tension and total SH groups decreased continuously throughout the storage. In addition, foaming properties slightly declined due to accumulation of salt content with extended storage. Conversely, the yield stress - an important indicator of foam quality - increased from 32.33 to $70.55 \%$ during storage. Overall, the egg whites could possibly serve as a key and/or a substitute ingredient in foam-based food products.
\end{abstract}

Keywords: duck egg; salting; egg white; storage; foaming properties

\footnotetext{
*Author for correspondence: karthikeyan.v@psu.ac.th
} 


\section{INTRODUCTION}

Salting duck eggs is an important traditional preservation technique that originated in China, and such eggs are widely produced and consumed in South-East Asia, especially in Thailand. There are two traditional ways to prepare them, namely by soaking the eggs in brine and/or by coating the eggs with salted mud clay and holding them for a curing period of around 2 to 4 weeks ${ }^{[1]}$. In Thailand, the Chaiya district in Surat Thani province is one of the major producers of salted duck eggs. Normally, the egg yolk has more demand than the egg white, as it is used as a stuffing agent in pastries or related bakery products, particularly in mooncakes. Apart from use in bakery products, whole eggs are occasionally consumed as hard-boiled or fried, and/or hardboiled eggs are chopped and added in a famous local Thai food, 'somtam kaowpot.' Egg white has low economic value, and often it is discarded due to its extremely salty taste preventing daily consumption, and also there are health concerns from high salt doses in food. Several studies have pursued removing excess salt content from the egg whites, or producing egg white powder ${ }^{[2-3]}$. However, removing salt or re-formulating the egg white are costly propositions. Generally, the egg whites contain abundant levels of protein that exhibits various functional properties, particularly foaming, gelling, binding adhesion, and emulsification abilities that are used in various food products ${ }^{[4]}$. Egg white can able to form high voluminous stable foams. Due to its excellent foaming properties, egg white protein is widely applied in the food industry to develop and maintain the quality of aerated foods, mainly baked products (cakes, breads, crackers, meringues, angel cake) and chocolate mousses ${ }^{[5]}$. Foam is a metastable colloidal system with dispersed gas bubbles in a continuous liquid medium, and the closed foam cells are separated by lamellae ${ }^{[6]}$. Naturally, the foaming properties of a protein are related to its degree of hydrophilicity and hydrophobicity, ability to form a film at the air-water interface and its nature of disconformity upon processing ${ }^{[7-8]}$. Furthermore, surface hydrophobicity of the egg white plays major role on improving the foaming properties. Ovalbumin is the main protein constituting 54\% of total protein in duck egg white, and it contains free $\mathrm{SH}$ groups, but during processing the functionality of this protein is diminished ${ }^{[9-11]}$. Several studies have reported on processing to alter the native state of egg white protein, especially to decrease foaming; pickling, freezing, heat, pressure and ultrasound treatments have been tested ${ }^{[4,11-13]}$. On the other hand, there have been very few studies conducted on the salted duck egg white. The present study was aimed to explore the influences of prolonged curing and storage on the duck egg white quality and foaming properties.

\section{MATERIALS AND METHODS}

\section{Raw Material}

The whole duck eggs (Khaki Campbell, Anas platyrhynchos domesticus) were purchased from a producer in Chaiya district, Surat Thani province, Thailand. The eggs were collected during a single day, after they had been covered with salted mud clay followed by coating with charcoal mixed rice husks (a traditional method). The eggs were carefully transported to the laboratory and kept for shelf life studies at room temperature for a period of 30 days. Every 5 days' eggs were sampled, the coating was removed from the surface, and they were thoroughly washed with tap water and cracked open to separate the egg white carefully for analysis. 


\section{Analysis}

\section{Physicochemical Analysis}

\section{Determination of Salt Content}

Salt content was measured in egg white using the method of Tan ${ }^{[14]}$. Egg white $(5 \mathrm{~g})$ was diluted to $100 \mathrm{~mL}$ using DI water, then $25 \mathrm{~mL}$ of diluted egg white sample was transferred to a conical flask $(250 \mathrm{~mL})$, and then $50 \mathrm{~mL}$ of $\mathrm{AgNO}_{3}$ was added, followed by $20 \mathrm{~mL}$ of concentrated $\mathrm{HNO}_{3}$. Then, the samples were mixed and boiled in a sand bath until $\mathrm{AgNO}_{3}$ was completely dissolved, as indicated by a clear solution. After that, $50 \mathrm{~mL}$ of DI water was added to the flask, followed by $5 \mathrm{~mL}$ of ferric alum indicator (5\%). Then, the solution was titrated with $0.1 \mathrm{M}$ KSCN solution until a permanent reddish brown color was obtained. The following formula was used to calculate the salt concentration in the egg white.

Salt content $(\%, \mathrm{w} / \mathrm{w})=\left(\mathrm{M} \times \mathrm{V}_{\mathrm{t}} \times 100 \times 10^{2} \times 58.5\right) /\left(10^{3} \times \mathrm{V}_{5} \times \mathrm{W}\right)$

$\mathrm{M}$ represents the concentration of $0.1 \mathrm{~m} \mathrm{AgNO}_{3}, \mathrm{~V}_{\mathrm{t}}$ represents the volume of $\mathrm{AgNO}_{3}$ used for titration $(\mathrm{mL}), 100$ represents the volume of sample $(\mathrm{mL}), \mathrm{V}_{5}$ is the volume used to analyze $(\mathrm{mL}), 10^{2}$ represents the conversion factor of $1-100 \mathrm{~g}$, W represents the weight of sample and 58.5 represent the molecular weight of $\mathrm{NaCl}$.

\section{Moisture Content and Water Activity}

Moisture content in the egg white was determined using an infrared moisture analyzer (MA160, Sartorius, Germany). The water activity of egg white was measured using a water activity analyzer (Aqualab, USA).

\section{Surface Hydrophobicity (Ho)}

The egg white was determined for Ho following the method of Duan ${ }^{[5]}$. A sample was diluted to five concentrations (between $0.0 \%$ and $0.1 \%$ protein) using phosphate buffer solution (10 mM, pH 7). Then, $4 \mathrm{~mL}$ aliquots were mixed with $20 \mathrm{~mL}$ of ANS $(8 \mathrm{mM})$ and kept in the dark for $3 \mathrm{~min}$, then placed in the fluorescence spectrophotometer and measured at $470 \mathrm{~nm}$, using excitation at $390 \mathrm{~nm}$ with $5 \mathrm{~nm}$ width. The buffer was used as a blank. Surface hydrophobicity is expressed as Ho as determined using the slope method.

$p H$

The egg white sample was measured for its $\mathrm{pH}$ using a digital $\mathrm{pH}$ meter.

\section{Determination of Zeta Potential and Particle Size}

The zeta potential and particle size off egg white were determined in accordance with $\mathrm{Li}^{[15]}$. Zeta potential was measured using the Zeta plus zeta potential analyzer (Brookhaven Instruments Cooperation, Holtsville, NY) at room temperature, and the results are expressed in $\mathrm{mV}$. The particle size was determined using backscatter detection at $170^{\circ}$ scattering angle. The sample was equilibrated for $60 \mathrm{~s}$ in the instrument before the data were collected at $25^{\circ} \mathrm{C}$. The results are expressed in $\mathrm{nm}$.

Surface Tension 
Surface tension of egg white was determined based on the method of $\mathrm{Gu}^{[16]}$. It was measured using an automatic surface tensiometer (DCAT21, Data Physics Instruments $\mathrm{GmbH}$, Germany) at $25^{\circ} \mathrm{C}$, and the set measuring range was from 1 to $1000 \mathrm{mN} / \mathrm{m}$.

\section{Determination of SH groups}

The egg white was measured for SH groups (total SH groups and exposed SH groups) using Ellman's reagent (5,5'-dithiobis 2-nitrobenzoic acid; DTNB) ${ }^{[17]}$. For measuring the exposed SH groups, $5 \mathrm{~mL}$ of egg white was added to $5 \mathrm{~mL}$ of Tris-glycine buffer (pH 8) containing $0.1 \mathrm{M}$ Tris, $0.1 \mathrm{M}$ glycine, and $4 \mathrm{mM}$ EDTA. Then, $0.1 \mathrm{~mL}$ of Ellman's reagent (4 mg/mL DTNB in Tris-glycine buffer) was added to the samplebuffer mixture that was kept at ambient temperature for $15 \mathrm{~min}$, and then it was centrifuged at $19,000 \mathrm{~g}$ for $15 \mathrm{~min}$ at $4^{\circ} \mathrm{C}$. The supernatant was collected and measured at $412 \mathrm{~nm}$. For measuring total $\mathrm{SH}$ groups, the steps above were similar except for the incubation temperature: the reaction mixture was kept at $40^{\circ} \mathrm{C}$ for 15 min in a water bath to let the protein unfold so all the SH groups could react with DTNB. After incubation, samples underwent centrifugation and measurement as in the exposed SH group determinations. SH content is expressed as a molar coefficient $\left(13,600 \mathrm{M}^{-1} \mathrm{~cm}^{-1}\right)$.

\section{Foaming Properties}

The collected duck egg whites $(250 \mathrm{~mL})$ were made into foams by using an electric kitchen mixer (Cuzimate, RBSFOODMIXERPRO, Thailand) with a $4.5 \mathrm{~L}$ stationary bowl and rotating beaters. Initially the whipping speed was set to level 3 for 5 min, and then it was increased level 4 for $10 \mathrm{~min}$. After whipping, the foam was carefully collected and analyzed for foam properties, namely index of whipping (IW), index of foam durability (ID at $30 \mathrm{~min}$ (ID30) and ID at $60 \mathrm{~min}$ (ID60)), specific density (SD), Overrun $\left(\mathrm{O}_{\mathrm{R}}\right)$, and Air phase $\left(\mathrm{A}_{\mathrm{P}}\right)$. These were measured in accordance with Bovšková and Míková ${ }^{[18]}$. Foam yield stress was measured using a digital viscometer with the method of Pernell ${ }^{[19]}$.

\section{Statistical Analysis}

All the determinations in this study were done in six replications. The data are expressed as mean \pm standard deviation. One-way analysis of variance was applied to determine significant differences $(\mathrm{P}<0.05)$ using SPSS v6 for Windows (IBM, NY, USA). Duncan's multiple range test was used to further assess significances of the mean differences.

\section{RESULTS AND DISCUSSION}

\section{Salt content, moisture, and water activity}

The changes in salt content, moisture level and water activity in the egg white of duck egg during prolonged storage under salted mud coatings are shown in Figure 1. Prolonged curing was significantly affected salt and moisture levels in the egg white: salt content gradually increased from $0.5 \%$ to $2.89 \%$. During curing salt had to diffuse from outside the eggshell to egg white and yolk. Previous studies have also observed increasing salt content in duck eggs during prolonged pickling ${ }^{[1,20]}$. On the other 
hand, osmosis adversely affected the moisture level of egg white that decreased from 86.8 to 82.6 , while the water activity decreased from 0.996 to 0.975 . Moisture content of egg white continuously decreased throughout the storage. A reduction in the egg white moisture was due to the cause of addition of moisture from the egg yolk as it released the moisture and got hardened by the diffusion effect of salt during the storage ${ }^{[1]}$. The observed decrease in water activity of egg white was not statistically significant. Lo ${ }^{[21]}$ reported that increased salt and decreased moisture significantly influenced the water activity in the eggs. The apparently smallish changes significantly affected the functional properties of egg white as can be seen in Table 1.

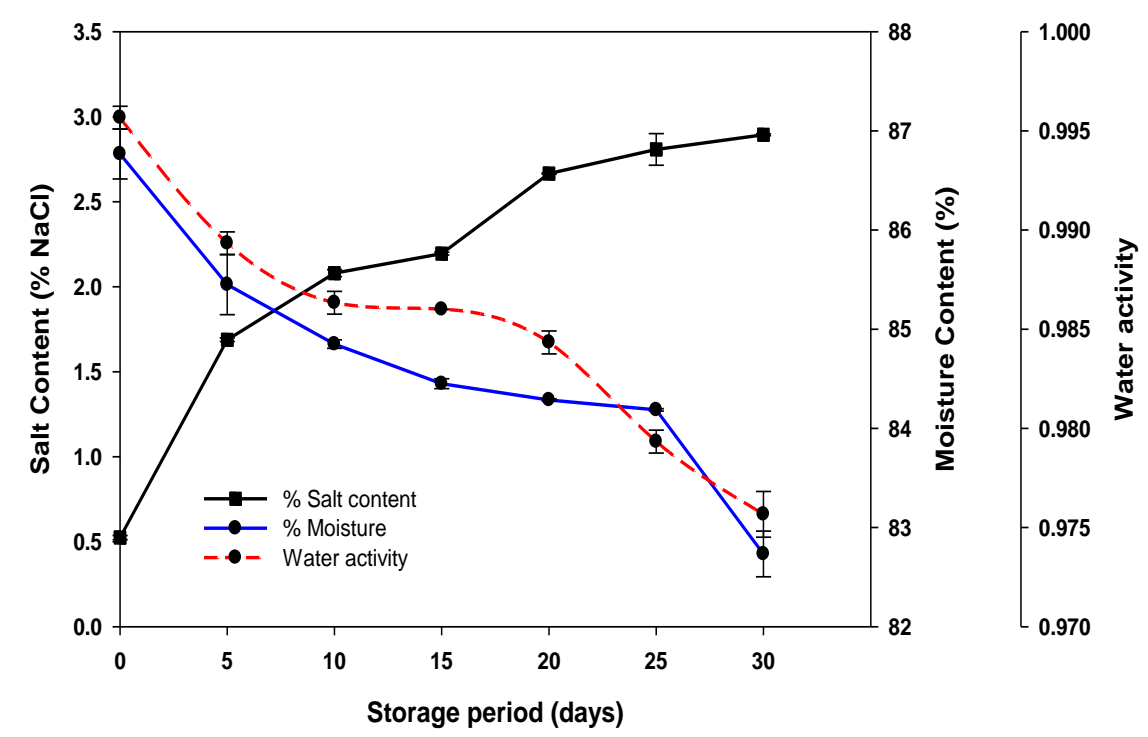

Figure 1. Time profiles of salt content, moisture and water activity in egg white under prolonged storage of duck eggs in salted mud coating. Data are shown as mean and SD.

\section{pH and surface hydrophobicity $(\mathrm{Ho})$}

A slight decrease in $\mathrm{pH}$ level was observed in egg white during prolonged storage: the $\mathrm{pH}$ declined from 8.65 to 7.4 (Figure 2). It might be the interaction between the egg headspace $\mathrm{CO}_{2}$ and the egg white moisture content and lead to form carbonic acid in egg, which is acidic in nature. However, a declining $\mathrm{pH}$ in the salted duck egg white is still in between the range of egg white natural $\mathrm{pH}$ level (7.6 to 9.7). The $\mathrm{Ho}$ of the egg white increased from 180 to 308 . The salted mud coating during extended storage significantly affected both $\mathrm{pH}$ and $H o$ (Figure 2). Ho plays a key role in the adsorption of proteins at a gas-liquid interface. Normally, it is related to the molecular size, conformational stability and net charge of the protein ${ }^{[22]}$. Shaw ${ }^{[23]}$ reported that $\mathrm{pH}$ plays a critical role in the net charge of the protein and its hydrophobicity. In another study, $\mathrm{Li}^{[15]}$ reported that decreasing the $\mathrm{pH}$ (between $\mathrm{pH} 7$ and 4) increased negative net charge on the protein and supported more surface hydrophobicity. This is in accordance with the present study, which showed the higher $\mathrm{Ho}$ at $\mathrm{pH}$ 7. In addition, increasing salt content could also increase the $\mathrm{Ho}$ : Kaewmanee ${ }^{[10]}$ reported that increasing the concentration of $\mathrm{NaCl}$ in duck egg white increased the $\mathrm{Ho}$. Croguennec ${ }^{[24]}$ and Lindman ${ }^{[25]}$ reported that increasing salt concentration could adversely affect the net charge of the protein making it hydrophobic. 


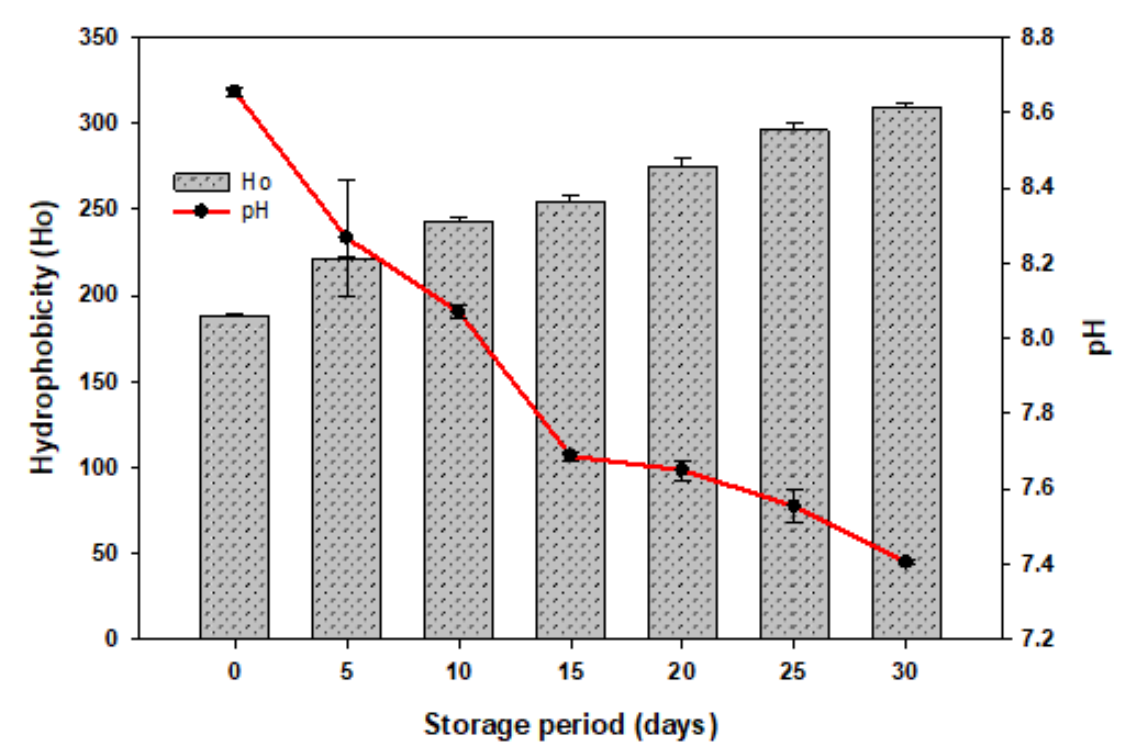

Figure 2. Time profiles of hydrophobicity and $\mathrm{pH}$ in egg white under prolonged storage of duck eggs in salted mud coating. Data shown are mean and SD.

\section{Zeta potential and particle size}

The extended salting significantly affected the zeta potential and particle size in the egg white of duck egg (Figure 3A). The results show that prolonged storage significantly decreased the zeta potential in egg white $(\mathrm{P}<0.05)$. Normally, zeta potential is used as an indicator of the stability of a colloidal system with three states of matter: gas, liquid and solid. Decreasing zeta potential here was mainly related to $\mathrm{pH}$ and salt content. Generally, a negative charge is exhibited when $\mathrm{pH}$ exceeds 7 . This is in accordance with the present research where the $\mathrm{pH}$ was between 7.2 and 8.8. In addition, Kaewmanee ${ }^{[10]}$ reported that increased $\mathrm{NaCl}$ concentration could diminish the zeta potential in egg white, as the $\mathrm{Na}^{+}$ions could neutralize the negative charges on the protein. On the other hand, the particle size of egg white gradually increased with storage and curing. At the beginning of curing, the particle size was $256 \mathrm{~nm}$, and then it increased to 2481 by the end of storage. An increment in particle size could indicate protein aggregation ${ }^{[26]}$. Kastelic ${ }^{[27]}$ reported that increased salt concentration might increase protein aggregation. Van der Plancken ${ }^{[11]}$ reported that the exposed SH group could be highly reactive at neutral or alkaline $\mathrm{pH}$ and cause protein aggregation. This is in accordance with the present study, which shows increased SH groups and neutral $\mathrm{pH}$ for the egg white (see Figure 2 and $3 \mathrm{~B}$ ). $\mathrm{Li}^{[28]}$ also reported that increased salt concentration might increase the particle size. This finding is in accordance with the present study as the salt concentration increased in the sample during prolonged storage, with matching trends in zeta potential and particle size of the egg white.

\section{Surface tension and SH groups}

The changes in surface tension and SH groups of egg white are shown in Figure 3B. The surface tension of egg white is an important determinant of the foam properties [29]. The surface tension of the egg white continuously decreased during storage and curing from 37.7 to $27 \mathrm{mN} / \mathrm{m}$ during the study period. This could be an affinity effect of $\mathrm{pH}$ and $\mathrm{NaCl}$, via the accumulation and shifting of net charges on the duck egg white. Kumeno ${ }^{[12]}$ reported that decreased surface tension in egg white could be a 
good indicator for ability to form stable foams. $\mathrm{Li}{ }^{[28]}$ reported that sodium chloride slightly decreased the egg white surface tension and its concentration was higher in the yolk of a chicken egg. Sulfhydryl groups ( $\mathrm{SH})$, both total $\mathrm{SH}$ groups and exposed SH groups, steadily changed in duck egg white during the storage with salted mud coating (Figure 3B). Ovalbumin is the only protein in egg white with free SH groups that exist in its native form in the interior of the protein structure, but salt could have induced partial denaturation of egg white, thereby exposing SH groups and decreasing total $\mathrm{SH}$ groups. The results show that total $\mathrm{SH}$ groups tended to decrease (from 3.37 to 2.80) throughout storage, whereas the exposed $\mathrm{SH}$ groups gradually increased (from 0.9 to 1.55$)(\mathrm{P}<0.05)$. A previous study reported that increasing salt concentration could reduce the total SH groups in duck egg white ${ }^{[10]} . \mathrm{Wu}{ }^{[30]}$ reported that peroxyl radicals generated during the processing could react with the sulfhydryl groups to form sulphinyl radicals and decrease the free SH groups in egg white. Katekhong and Charoenrein ${ }^{[17]}$ also observed a lower level of total SH groups and a higher level of exposed SH groups in egg white.
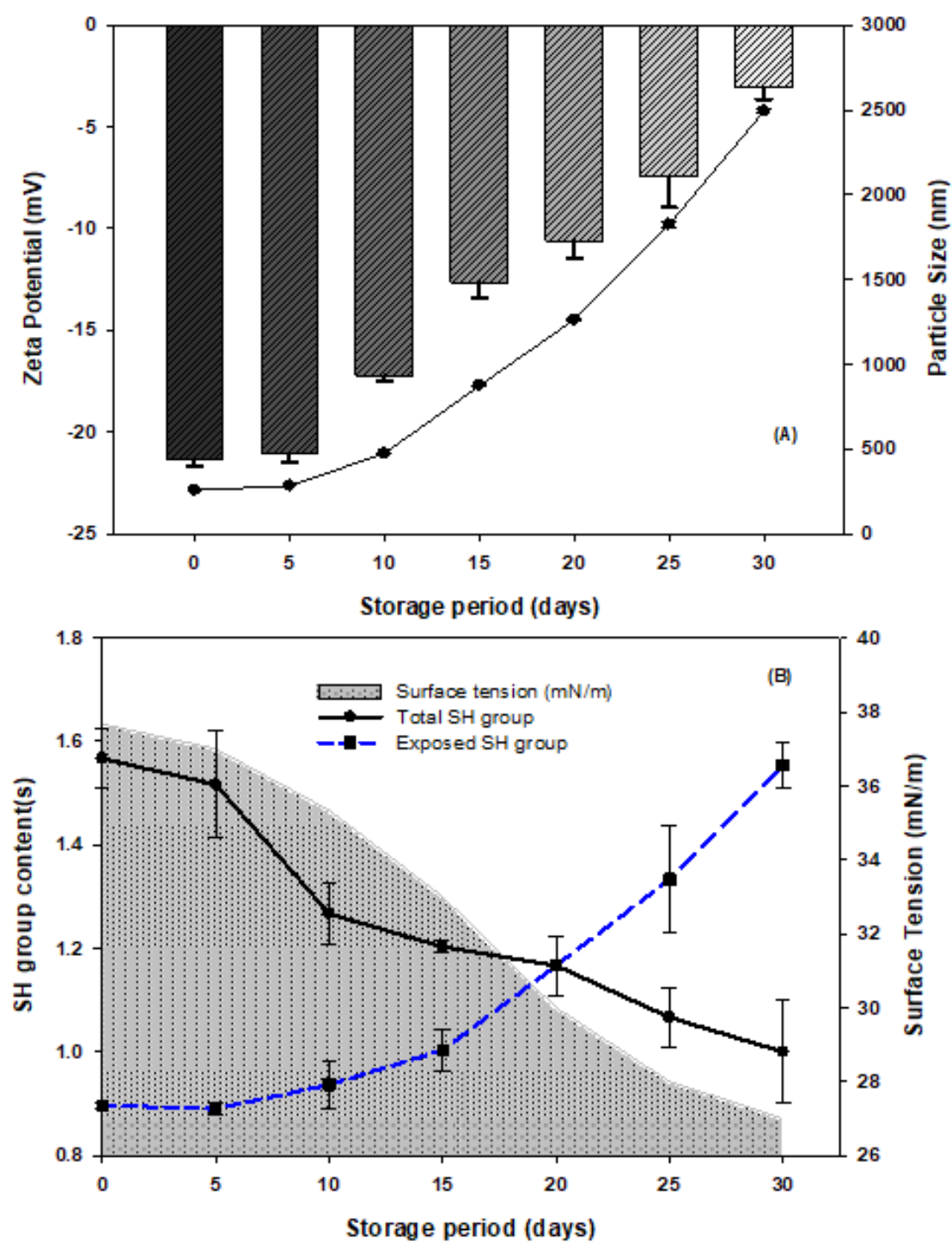

Figure 3. Time profiles of zeta potential (A), particle size (A), surface tension (B) and SH group(s) (B) in egg white under prolonged storage of duck eggs in salted mud coating. Data shown are mean and SD $(n=6)$. 


\section{Foaming properties}

Foams are characterized on the basis of appearance, overrun, gas phase volume, rheology, and stability ${ }^{[31]}$. The changes in foaming properties (IW, ID30, ID60, SD, OR, AP and YS) of duck egg white are presented in Table 1. Normally, the foaming properties of a sample vary by preparation, equipment, and method used. There was a decreasing trend observed in the foaming properties mainly in IW, ID30 and 60, SD and OR. On the other hand, AP and YS gradually increased. IW represents the foam forming capacity of egg white, and the results show that prolonged storage and curing slightly decreased foaming capacity. Ihara ${ }^{[32]}$ reported that whipping properties of a protein are normally influenced by the air bubble factors, such as overrun, diameter and surface area. Raikos ${ }^{[13]}$ observed improved hen egg white foaming capacity after addition of salt. It was indicated that the source of samples also influences the foaming capacity. The ID, which represents the stability of foam, also declined progressively. However, on comparing foam stabilities of egg whites by durability (ID30 and ID60) the differences are smallish. Previous studies have reported that foam stability of egg white is higher at alkaline $\mathrm{pH}$, and it tends to decline with decreasing $\mathrm{pH}^{[18-33]}$. Alleoni and Antunes ${ }^{[34]}$ reported that prolonged storage could transform the n-ovalbumin to sovalbumin and consequently interfere at the air-water interfaces of the foam causing instability. SD of the foam slightly decreased during storage, although without statistical significance. Similarly, the OR also decreased during storage, with significant difference between the initial and final values $(\mathrm{P}<0.05)$. Hammershoj and Larsen ${ }^{[35]}$ reported elevated OR in egg foam with $\mathrm{pH}$ below 5 . On the other hand, the AP of egg white foam was not significantly affected, with only slight initial increase and then a stable value throughout the rest of storage $(\mathrm{P}>0.05)$. So, prolonged curing did not affect the AP. Furthermore, the YS of foam increased steadily during the storage, so the highest value was observed at the end of storage. Luck ${ }^{[31]}$ reported that egg protein is able to form foams with higher yield stress at low protein concentrations and with less whipping time than proteins from alternative sources. Overall, the results on foaming properties show that increasing salt concentration in the egg white during prolonged curing significantly affected the foaming ability and foam stability of egg white $(\mathrm{P}<0.05)$ 
Table 1. Foam characteristics of egg white from salted duck eggs at various storage times

\begin{tabular}{|c|c|c|c|c|c|c|c|}
\hline $\begin{array}{l}\text { Storage Period } \\
\text { (days) }\end{array}$ & Iw $(\%)$ & ID30 (\%) & $\operatorname{ID60}(\%)$ & $\mathrm{SD}(\mathrm{g} / \mathrm{mL})$ & OR $(\%)$ & $\mathbf{A P}$ & YS (\%) \\
\hline $\mathbf{0}$ & $691.61 \pm 12.45^{a}$ & $683.94 \pm 13.53^{\mathrm{a}}$ & $669.11 \pm 13.62^{\mathrm{a}}$ & $0.18 \pm 0.00^{\mathrm{a}}$ & $89.61 \pm 1.07^{\mathrm{a}}$ & $0.46 \pm 0.004^{\mathrm{ns}}$ & $32.33 \pm 4.17^{\mathrm{d}}$ \\
\hline 5 & $682.61 \pm 10.77^{b}$ & $672.61 \pm 11.20^{b}$ & $653.44 \pm 11.96^{\mathrm{b}}$ & $0.16 \pm 0.01^{b}$ & $89.34 \pm 0.45^{\mathrm{a}}$ & $0.47 \pm 0.001^{\mathrm{ns}}$ & $35.42 \pm 6.65^{d}$ \\
\hline 10 & $677.91 \pm 14.60^{\mathrm{bc}}$ & $663.52 \pm 15.84^{c}$ & $645.19 \pm 12.12^{b c}$ & $0.15 \pm 0.00^{b}$ & $88.43 \pm 0.39^{\mathrm{ab}}$ & $0.47 \pm 0.001^{\mathrm{ns}}$ & $39.28 \pm 2.88^{c}$ \\
\hline 15 & $671.86 \pm 11.43^{b c}$ & $652.83 \pm 11.37^{\mathrm{cd}}$ & $627.23 \pm 11.43^{\mathrm{cd}}$ & $0.15 \pm 0.01^{b}$ & $87.88 \pm 0.87^{\mathrm{ab}}$ & $0.47 \pm 0.003^{\mathrm{ns}}$ & $40.85 \pm 5.69^{c}$ \\
\hline 20 & $660.52 \pm 5.61^{\mathrm{c}}$ & $648.06 \pm 4.57^{\mathrm{cd}}$ & $616.58 \pm 5.05^{\mathrm{e}}$ & $0.14 \pm 0.00^{c}$ & $88.50 \pm 0.60^{\mathrm{ab}}$ & $0.47 \pm 0.002^{\mathrm{ns}}$ & $44.02 \pm 4.36^{\mathrm{bc}}$ \\
\hline 25 & $655.56 \pm 21.21^{\mathrm{cd}}$ & $635.69 \pm 41.30^{\mathrm{e}}$ & $611.84 \pm 48.87^{\mathrm{ef}}$ & $0.14 \pm 0.00^{c}$ & $88.43 \pm 1.06^{\mathrm{ab}}$ & $0.47 \pm 0.003^{\mathrm{ns}}$ & $46.74 \pm 0.31^{\mathrm{b}}$ \\
\hline 30 & $642.67 \pm 4.04^{\mathrm{e}}$ & $626.34 \pm 9.06^{\mathrm{f}}$ & $606.85 \pm 11.12^{\mathrm{f}}$ & $0.14 \pm 0.00^{c}$ & $85.02 \pm 1.03^{b}$ & $0.47 \pm 0.003^{\mathrm{ns}}$ & $70.55 \pm 2.30^{\mathrm{a}}$ \\
\hline
\end{tabular}

Note: Data shown are mean and SD ( $\mathrm{n}=6)$. Different superscripts within one column indicate significant differences at $\mathrm{P}<0.05$ and $\mathrm{ns}$ indicates non-significant $(\mathrm{P}>0.05)$. Iw Index of whipping; ID30 - Index of foam durability at $30 \mathrm{~min}$; ID60 - Index of foam durability at 60 min; SD - Specific density; OR - Overrun; AP - Air phase; YS - Yield stress. 


\section{CONCLUSION}

The present study revealed that salted mud coated duck egg had significant changes under prolonged storage in the functional properties of egg white. $\mathrm{NaCl}$ from the mud coating was gradually infused into the egg white during the storage, but remained below 3.5\%. It significantly affected the zeta potential, hydrophobicity, and $\mathrm{SH}$ groups in the egg white. Furthermore, the foaming properties were also influenced by $\mathrm{NaCl}$ accumulation and by altered $\mathrm{pH}$ of the egg white, although only slightly. Duck egg whites after prolonged curing are normally considered as having only low economic value, and these results suggest that salted egg whites could be used to develop value-added foambased food products particularly meringue.

\section{ACKNOWLEDGMENT}

The author is very grateful to the Research and Development Organization, Prince of Songkla University, Hatyai Campus and also to the Surat Thani Campus for funding this project (Project grant no. SIT601320S). The author would also like to acknowledge the additional financial support by the Prince of Songkla University, Surat Thani Campus, in 2016. In addition, the Food Innovation and Product Development (FIPD) Laboratory is acknowledged for providing laboratory space and equipment support.

\section{REFERENCES}

1. Kaewmanee T, Benjakul S, Visessanguan W. Protein hydrolysate of salted duck egg white as a substitute of phosphate and its effect on quality of Pacific white shrimp (Litopenaeus vannamei). J Food Sci. 2009; 74(8): 351-361.

2. Hou T, Liu W, Shi W, Ma Z, He H. Desalted duck egg white peptides promote calcium uptake by counteracting the adverse effects of phytic acid. Food Chem. 2017; 219: 428-435.

3. Wang Y, Zheng H, Li Y, Li B, Chen Y. One step procedure for desalting salty egg white and preparing fat analogue and its application in mayonnaise. Food Hydrocol. 2015; 45: $317-$ 326.

4. Arzeni C, Pérez OE, Pilosof AMR. Functionality of egg white proteins as affected by high intensity ultrasound. Food Hydrocol. 2012; 29(2): 308-316.

5. Duan X, Li M, Shao J, Chen H, Xu X, Jin Z, Liu X. Effect of oxidative modification on structural and foaming properties of egg white protein. Food Hydrocol. 2018; 75: 223-228.

6. Hill C, Eastoe J. Foams: From nature to industry. Advan Col Interf Sci. 2017; 247: 496513.

7. Du L, Prokop A, Tanner RD. Effect of denaturation by preheating on the foam fractionation behavior of ovalbumin. J Col Interf Sci. 2002; 248(2): 487-492.

8. Lomakina K, Mikova K. A study of the factors affecting the foaming properties of egg white-a review. Czech J Food Sci. 2006; 24(3): 110-118.

9. Alleoni CCA. Albumen protein and functional properties of gelation and foaming. Scient. Agric. 2006; 63(3): 291-298.

10. Kaewmanee T, Benjakul S, Visessanguan W. Effect of $\mathrm{NaCl}$ on thermal aggregation of egg white proteins from duck egg. Food Chem. 2011; 125(2): 706-712.

11. Van der Plancken I, Van Loey A, Hendrickx ME. Changes in sulfhydryl content of egg white proteins due to heat and pressure treatment. J Agric Food Chem. 2005; 53(14): 57265733.

12. Kumeno K, Kurimoto K, Nakahama N, Watanabe M. Functional Properties of Freezeconcentrated Egg White Foam and Its Applications for Food Processing. Biosci Biotech Biochem. 1994; 58(3): 447-450. 
13. Raikos V, Campbell L, Euston SR. Effects of sucrose and sodium chloride on foaming properties of egg white proteins. Food Res Intern. 2007; 40(3): 347-355.

14. Tan T-C, Phatthanawiboon T, Mat Easa A. Quality, Textural, and Sensory Properties of Yellow Alkaline Noodles Formulated with Salted Duck Egg White. J Food Qual. 2016; 39(4): 342-350.

15. Li R, Wu Z, Wang Y, Ding L, Wang Y. Role of $\mathrm{pH}$-induced structural change in protein aggregation in foam fractionation of bovine serum albumin. Biotech Rep. 2016; 9: 46-52.

16. Gu L, Su Y, Zhang M, Chang C, Li J, McClements DJ, Yang Y. Protection of $\beta$-carotene from chemical degradation in emulsion-based delivery systems using antioxidant interfacial complexes: Catechin-egg white protein conjugates. Food Res Inter. 2017; 96: 84-93.

17. Katekhong, W, Charoenrein S. Color and gelling properties of dried egg white: Effect of drying methods and storage conditions. Inter J Food Prop. 2017; 20(9): 2157-2168.

18. Bovšková H, Míková K. Factors influencing egg white foam quality. Czech J Food Sci. 2011; 29(4): 322-327.

19. Pernell CW, Foegeding EA, Luck PJ, Davis JP. Properties of whey and egg white protein foams. Colloids and Surfaces A: Physicochem Engineer Asp. 2002; 204(1): 9-21.

20. Xu L, Zhao Y, Xu M, Yao Y, Nie X, Du H, et al. Effects of salting treatment on the physicochemical properties, textural properties, and microstructures of duck eggs. PLOS ONE. 2017; 12(8): e0182912.

21. Lo YC, Froning GW, Arnold RG. The Water Activity Lowering Properties of Selected Humectants in Eggs. Poultry Sci. 1983; 62(6): 971-976.

22. Karbaschi M, Lotfi M, Krägel J, Javadi A, Bastani D, Miller R. Rheology of interfacial layers. Cur Opin Col Interf Sci. 2014; 19(6): 514-519.

23. Shaw KL, Grimsley GR, Yakovlev GI, Makarov AA, Pace CN. The effect of net charge on the solubility, activity, and stability of ribonuclease Sa. Protein Sci. 2001; 10(6): 12061215.

24. Croguennec T, Nau F, Brulé G. Influence of $\mathrm{pH}$ and salts on egg white gelation. $J$ Food Sci. 2002; 67(2): 608-614.

25. Lindman S, Xue FW, Szczepankiewicz O, Bauer MC, Hanna N, Linse S. Salting the charged surface: $\mathrm{pH}$ and salt dependence of protein G B1 stability. Biophys J. 2006; 90: 29112921.

26. Amin S, Barnett GV, Pathak JA, Roberts CJ, Sarangapani PS. Protein aggregation, particle formation, characterization \& rheology. Cur Opin Col Interf Sci. 2014; 19(5): 438-449.

27. Kastelic M, Kalyuzhnyi YV, Hribar-Lee B, Dill KA, Vlachy V. Protein aggregation in salt solutions. Proceed Nation Acad Sci. 2015; 112(21): 6766-6770.

28. Li J, Wang C, Li X, Su Y, Yang Y, Yu X. Effects of $\mathrm{pH}$ and $\mathrm{NaCl}$ on the physicochemical and interfacial properties of egg white/yolk. Food Bioscience. 2017; https://doi.org/10.1016/j.fbio.2017.12.004.

29. Awad RA, Hassan ZMR, Salama MW. Surface tension and foaming properties as a simple index in relation to buffalo milk adulteration. Inter J Dairy Sci. 2014; 9(4): 106-115.

30. Luck PJ, Bray N, Foegeding EA. Factors determining yield stress and overrun of whey protein foams. J Food Sci. 2002; 67(5): 1677-1681.

31. Ihara K, Habara K, Ozaki Y, Nakamura K, Ochi H, Saito H, et al. Influence of whipping temperature on the whipping properties and rheological characteristics of whipped cream. $J$ Dairy Sci. 2010; 93(7): 2887-2895.

32. Bovšková H, Míková K. Factors influencing egg white foam quality. Czech J Food Sci. 2011; 29(4): 322-327.

33. Nakamura R, Sato Y. Studies on the foaming property of the chicken egg white. Agric Biol Chem. 1964; 28: 530-534.

34. Alleoni ACC, Antunes AJ. Albumen foam stability and s-ovalbumin contents in eggs coated with whey protein concentrate. . Rev Bras Cienc Avic. 2004; 6: 105-110.

35. Hammershoj M, Larsen LB. Quality of Eggs and Egg Product. In: Cavalchini GC, Baroji D, editors, Proceeding IXth European Symposium on the Quality of Eggs and Egg Products; 1999. p. 351-357. 